Economics Series

No. 116, March 2011

Environmental Security and Its Implications for China's Foreign Relations

Junko Mochizuki and ZhongXiang Zhang

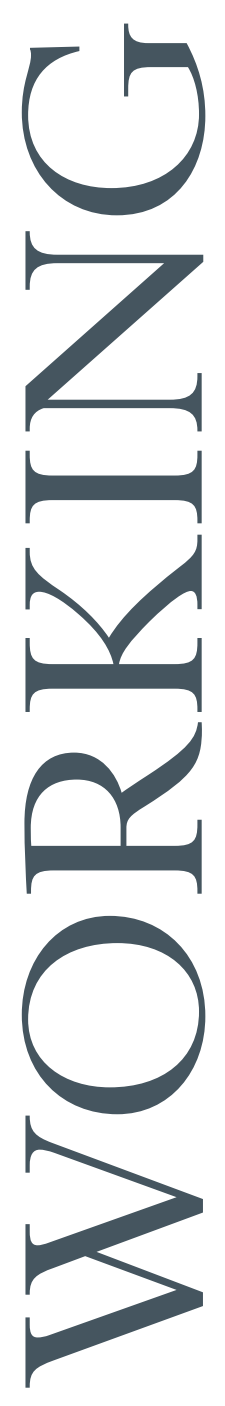

五 
The East-West Center promotes better relations and understanding among the people and nations of the United States, Asia, and the Pacific through cooperative study, research, and dialogue. Established by the U.S. Congress in 1960, the Center serves as a resource for information and analysis on critical issues of common concern, bringing people together to exchange views, build expertise, and develop policy options.

The Center's 21-acre Honolulu campus, adjacent to the University of Hawai'i at Mānoa, is located midway between Asia and the U.S. mainland and features research, residential, and international conference facilities. The Center's Washington, D.C., office focuses on preparing the United States for an era of growing Asia Pacific prominence.

The Center is an independent, public, nonprofit organization with funding from the U.S. government, and additional support provided by private agencies, individuals, foundations, corporations, and governments in the region.

East-West Center Working Papers are circulated for comment and to inform interested colleagues about work in progress at the Center.

For more information about the Center or to order publications, contact:

Publication Sales Office

East-West Center

1601 East-West Road

Honolulu, Hawai‘i 96848-1601

Telephone: 808.944 .7145

Facsimile: 808.944.7376

Email: EWCBooks@EastWestCenter.org

Website: EastWestCenter.org 
들 $\frac{\text { E A S T - W E S T C E N T E R }}{\text { Collaboration - expertise - leadership }}$

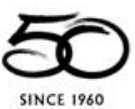

\section{Economics Series}

No. 116, March 2011

\section{Environmental Security and Its Implications for China's Foreign Relations}

\author{
Junko Mochizuki and ZhongXiang Zhang
}

Junko Mochizuki is a PhD student in the Department of Natural Resources and Environmental Management, University of Hawai' $i$ at Mānoa, United States.

ZhongXiang Zhang is a senior fellow at the East-West Center. Currently, he is a co-editor of both Environmental Economics and Policy Studies (the official journal of the Society of Environmental Economics and Policy Studies) and International Journal of Ecological Economics and Statistics, and serves on the editorial boards of nine leading international journals and two Chinese journals. Eleven of his publications are cited by IPCC Climate Change 2001: Mitigation and IPCC Climate Change 2007: Mitigation of Climate Change.

East-West Center Working Papers: Economics Series is an unreviewed and unedited prepublication series reporting on research in progress. The views expressed are those of the author and not necessarily those of the Center. Please direct orders and requests to the East-West Center's Publication Sales Office. The price for Working Papers is $\$ 3.00$ each plus shipping and handling. 
This version: February 2011

\title{
Environmental Security and its Implications for China's Foreign Relations $^{1}$
}

\author{
Junko Mochizuki \\ Department of Natural Resources and Environmental Management, University of Hawaii at Manoa, \\ the United States \\ ZhongXiang Zhang ${ }^{*}$ \\ Research Program, East-West Center, 1601 East-West Road, Honolulu, HI 96848-1601, the United \\ States
}

\begin{abstract}
China's emerging standing in the world demands a major rethinking of its diplomatic strategies. Given its population size, geographical scale, economic power and military presence, China is poised to play a larger political role in the twenty-first century, and is thus perceived by the international community to have greater capacities, capabilities and responsibilities. At the same time, environmental stresses caused by China's energy and resources demands have become increasingly evident in recent years, urging China to cultivate delicate diplomatic relations with its neighbors and strategic partners. Tensions have been seen in areas such as transboundary air pollution, cross-border water resources management and resources exploitation, and more recently in global issues such as climate change. As the Chinese leadership begins to embrace the identity of a responsible developing country, it is becoming apparent that while unabated resources demands and environmental deterioration may pose a great threat to environmental security, a shared sense of urgency could foster enhanced cooperation. For China to move beyond existing and probable diplomatic tensions, a greater attention to domestic and regional environmental security will no doubt be necessary. This article explores such interrelations among domestic, regional and global environmental securities and China's diplomacy, and suggests possible means by which China could contribute to strengthening global environmental security.
\end{abstract}

Keywords: Acid rain; Climate change; Energy; Environmental security; Transboundary air pollution; Water resource management; Asia

JEL classification: Q25; Q34; Q48; Q42; Q53; Q54; Q56; Q58; O13; P28

\footnotetext{
${ }^{1}$ Revised based on an invited presentation at the International Academic Workshop on Human Security in China's Foreign Relations, University of Victoria, Victoria, Canada, November 5-6, 2010.

* Corresponding author: ZhongXiang Zhang, Senior Fellow, Research Program, East-West Center, 1601 East-West Road, Honolulu, HI 96848-1601, USA. Tel.: +1-808-944 7265; fax: +1808-944 7298. E-mail address: ZhangZ@EastWestCenter.org.
} 


\section{Introduction}

The summer of 2010 marked two important milestones for China. On July 10, the International Energy Agency reported that China, whose energy demand was merely half that of the United States a decade ago, had surpassed the United States to become the world's largest energy consumer (IEA 2010a; IEA 2010b). This historic overtaking was met with little surprise from many, despite the immediate objection voiced by the Chinese government (Li 2010). On August 17, China again made global headlines as it overtook Japan as the world's second largest economy. Pundits and analysts alike asked: "When will China overtake the United States as the largest economy in the world?" (Tseng 2010; China Daily 2010a)

While the magnitude of China's transformation continues to attract considerable international attention, it needs only to be said that China's influence already extends to many facets of the world's economy. China ranks as the world's largest consumer of many major goods and commodities, including, steel (47\%), cement (55\%), wheat (16\%), and corn $(19 \%)^{2}$; and it is the world's largest producer of many more. Furthermore, China has been the world's largest $\mathrm{CO}_{2}$ emitter since 2007 (IEA 2007), in spite of its efforts to scale up energy efficiency and aggressively promote renewable energy use. Driven by the thirst for resources, China's diplomatic reach also extends to the farthest corners of Asia, Africa and Latin America. The changing configurations of the political and economic landscape, coupled with China's military presence, have inevitably unsettled the global balance of power. Consequently, China is increasingly seen as a major player within the international community, and as such, is pressed to fulfill greater responsibilities and demonstrate a greater capacity and transparency in addressing some of the most critical issues of our time.

Until now, China's economic growth has been fueled predominantly by the use of coal, which accounts for some two third of its total primary energy demand (Sun 2010). Such extensive coal dependency has come at considerable expense to public health and the environment (Zhang 2007b). Unabated demands for mineral, water and other natural resources have also continued to strain the country's meager supply of resources. The effects have been felt well beyond its national border, as seen in regional transboundary environmental problems such as acid rain and yellow dust, both highly publicized since the early 1990s. Now, an emerging consensus on the threat of climate change casts a new light on these challenges. As China assists its burgeoning economy by building a cascade of dams along the Mekong River (Osborne 2004; Goh 2009) and converting the country's Southwestern territories to rubber plantations (Ziegler et al. 2009), the environmental and social ramifications of such a rising demand for resources resonates across national borders, multiplying risks both to the region itself and to the world at large. At the same time, the threats of climate change are becoming increasingly visible in regions such as the Himalayas, where important glaciers feeding Asia's major rivers have shown signs of retreat (Yao et al.2007; Xu et al. 2008; Qiu 2008). These trends, together with uncertainty about the consequences of climate change, pose significant risks to global and regional security. It is now increasingly evident, therefore, that how China handles the environmental security issues arising from its growing demand for energy and resources will have decisive implications for its foreign relations.

This article explores the interrelationships among domestic, regional and global environmental securities and China's diplomacy. Following a brief discussion of the concept of environmental

${ }^{2}$ Steel use is 2009 figure calculated from World Steel Statistical Yearbook 2010 by World Steel Association; Cement use is 2009 figure estimated by the Japan Cement Association; Wheat and Corn Demand is 2008-2009 figure calculated from the World Agricultural Supply and Demand Estimates (WASDE) of the United States Department of Agriculture. 
security, the article focuses on certain key issues considered crucial for our understanding of environmental security and its implications for China's foreign relations. Specifically, it addresses the following questions: 1) which areas pose significant environmental security concerns for China and its neighbors? 2) how might environmental security be affected by the increase in global climate change and its associated uncertainty and risk? and 3) how can China best contribute to environmental security in the region? The article ends with some concluding remarks.

\section{Environmental Security: Conceptual Overview}

Environmental security, and its corollary concept of climate security, are a fairly recent topic of concern in the context of China's foreign relations. Historically speaking, however, the political and social implications of environmental and resources constraints have regularly prompted major scholarly inquiries. Within contemporary discourse, the environment and security nexus emerged as an important agenda in the 1980s, when critics began advocating the concept as an antithesis to the Cold War and to the disproportionate attention given to the military threat as the sole risk to national security (Allenby 2000; Dalby 2002; Haggman 2005; Raleight and Urdal 2007; Gleditsche 2007). Today, in light of concerns about the rise in climate change, the idea of environmental security - and climate security in particular - has gained renewed attention (Bernett 2003; Barnett and Adger 2007; Raleigh and Urdal 2007; Brown et al. 2007).

"Could the time be coming when as much lasting security can be purchased through trees as through tanks?" asked Norman Myers in his 1989 Foreign Policy article "Security and Environment". In his article, Myers highlighted how environmental stresses in already fragile states might undermine the economic, political and military interests of the United States, and hence urged that these concerns be addressed within the United States' strategic and national security planning. Similar views were also expressed in earlier works on the environment and security, including Galtung (1982) and Ullman (1983), which called for renewed political momentum towards a comprehensive redefinition of national security (Ronnfeld 1997). In addition, the increasing availability of scientific evidence for global environmental threats, including ozone depletion and global warming, meant that the traditional roles played by nationstates, geographical borders, and international agreements were no longer adequate. They also required significant redefinition (Mische 1993). "Put bluntly," as Jessica Mathews (1989) succinctly observed, "our accepted definition of the limits of national sovereignty as coinciding with national borders is obsolete" (p.174). As such, the contemporary notion of environmental security emerged as an alternative to the conventional state-centric and military-focused theory of security.

With the demise of the bipolar world and the rise of global environmental concerns, the idea of an alternative paradigm gained ever more popular support. However, a significant dissonance also emerged, on both a conceptual and an operational level, in terms of providing a clear and universal definition of environmental security (Graeger 1996; Barnett 2001). ${ }^{3}$ This was partly because the notion encompassed several complex and non-linear interactions among human, ecological and institutional variables (Homer-Dixon 1991). In addition, scholars and practitioners alike often disagreed as to the underlying motivations for, and practical merits of, bringing the two concepts of environment and security together (Levy 1995). In the environmental security literature, the nature and extent of these interrelations are predominantly shaped by the chosen

${ }^{3}$ For detailed discussions of theoretical evolution and the typology of environmental security, please see, for example, Ronnfeldt (1997). 
definitions of the terms "environment" and "security"; and both of these concepts are highly contextual, open to various interpretations. As Allenby (2000) states, "[e]nvironmental security, a relatively new and still somewhat contentious concept, may be defined as the intersection of environmental and national security considerations at a national policy level" (p.5). Here, Allenby defines national security within a series of subsets, i.e. foreign policy considerations, human security and humanitarian concern, and ultimately the larger considerations of global environmental stability. However, it remains unclear as to what specific factors should or should not be considered environmental security threats. Arguably, one of the most controversial interpretations of the linkage between these factors is the environment-conflict causal relationship, originally analyzed by Thomas Homer-Dixon and the "Toronto Group" as well as the "Environmental Conflict Project" by the Swiss Federal Institute of Technology and the Swiss Peace Foundation (Ronnfeldt 1997; Hagmann 2005). These empirical studies sought to test whether or not environmental issues (environmental degradations and/or scarcity of natural resources) could trigger acute and violent conflict in vulnerable regions. ${ }^{4}$

While such direct links (i.e. the premise that environmental issues "cause" violent conflicts) are more often than not refuted, it is commonly accepted that environmental degradation may act as a "threat-multiplier" (Homer-Dixon 1991). Furthermore, the notion of environmental degradation as a threat-multiplier is also widely established in the analysis of human security. Here, human security is defined as freedom from threats such as "hunger disease and repression" as well as "sudden and hurtful disruptions in the pattern of daily lives" (UNDP 1994). This human focus allows for an in-depth assessment of how environmental degradation may threaten people's wellbeing and thereby undermine environmental security, defined as "freedom from environmental destruction and resources scarcity" (Gleditsch 2007).

Amidst the ensuing conceptual debate, a growing number of national and international governing bodies have also taken steps to address the imperative of environmental/climate security. For example, the United Nations Security Council, the United Nations' primary body in charge of maintaining global peace and security, held its first discussion on climate change and security in April 2007. This landmark discussion was followed by the UN General Assembly's endorsement of Resolution 63/281 in June 2009, calling for intensified efforts by relevant organizations to work on issues of climate change and security (UN General Assembly 2009). Having traditionally approached climate change from the standpoint of development, the Chinese leadership initially resisted the idea of climate change as a national security imperative (Brown et al. 2007; Freeman 2010); however, such defiance is gradually waning as national security risks arising from climate change become more apparent. For example, the escalating importance of climate change as a security issue is exemplified in the recent establishment of the Military Climate Change Expert Commission within the Chinese People's Liberation Army (PLA). Formed in November 2008, the expert committee is comprised of key government agencies including the National Development

\footnotetext{
${ }^{4}$ Over the years, prolific debates have delineated some of the common themes of environmental security. In particular, securitization of environment/climate vs. desecuritization of security debate is a recurring theme in the security debate, significantly shaping our understanding of the notion of environmental security. These debates beg the question of whether marrying the two concepts broadens the realm of security, thereby convincing political leaders to protect "the security of [their] citizens above and beyond their military security" (Graeger 1996), or simply places "the debate into a political context dominated by institutions designed for completely different types of threat" (Buckland 2007, p.13). This is indeed one of the most challenging normative questions of environmental security, and as arguments exist both for and against linking security and environment/climate issues, debate is likely to continue.
} 
and Reform Commission (NDRC), the China Meteorological Administration (CMA), the Ministry of Science and Technology (MST), the Ministry of Foreign Affairs (MFA), and the National Natural Science Foundation of China (NSFC). It is expected to carry out research into the impact of climate change on military operations, and to serve as intelligence for future strategic planning (Freeman 2010). Moreover, the Chinese leadership increasingly perceives climate change as a "threat-multiplier" likely to damage security and social stability from the standpoint of food and water availability, as well as adversely affecting disaster risk reduction (Moore 2009).

\section{Implications for China's Foreign Relations}

\section{III.1 'Peaceful Development' vs. 'China Threat'}

China began to implement economic reform in late 1978, and joined the World Trade Organization (WTO) in December 2001. As the country's economy continues to grow, the world watches its emergence into the global market with considerable reservations. For outside observers, sources of anxiety include China's human rights background, its history of breaching intellectual property, product safety and rising military spending. These cast a looming shadow over China's growth, framing it as a potential destabilizing influence on the global status quo and balance of power. This tension was further exacerbated by China's rising demand for natural resources, and its political and ideological divide with the West. China's pragmatic diplomacy toward non-democratic states such as Sudan posed a great threat to Western democracies, which had traditionally alienated such states for strategic reasons (Zhang 2007a; Kaplan 2010). Moreover, growing disagreement about how responsibilities for climate change issues should be shared fairly and equitably has also added to diplomatic tension. This line of thinking, dubbed the 'China threat theory', still dominates much of the West's foreign policy discourse regarding China.

For China, a greater influence in the global market and open ties with the world also meant closer scrutiny from outsiders of its conduct and underlying intentions. At the same time, increasing disparities in domestic income and regional developmental divides have led to an existing paradox: while on the one hand China embraces its identity as a major new world power, on the other it is still very much a developing country, with almost half of China's total population lives on less than $\$ 2$ per day (using PPP conversion rates) (Hallding et al. 2009). In order both to respond to international reservations, and to overcome these domestic challenges, the Chinese leadership chose the path of so-called peaceful development, or he ping fa zhan, as its primary foreign policy doctrine. These progressive commitments to multilateralism, peace and achieving a 'moderately well-off society' by means of a scientific development approach were reaffirmed in China's Peaceful Development Road, the state council's white paper in 2005. China's environmental diplomacy is generally assumed to conform to the following guiding principles: serving internal political and economic interests; ensuring self-determination in domestic environmental affairs; representing the country as a responsible stakeholder; respecting the Five Principles of Peaceful Co-existence; and, finally, supporting the larger goals of Chinese diplomatic relations (Shouqiu and Voigts 1993; Zhao and Ortolano 2003).

\section{China's Climate Pledge - "Serious Commitment" or "Business as Usual"?}

While peaceful development remains China's official doctrine, it is debatable as to what extent this doctrine has assuaged the anxieties of the international community. Tensions which reflect mutual suspicion as well as ideological and cultural differences remain prevalent in foreign policy discourse, including that of climate change. As China became the largest $\mathrm{CO}_{2}$ emitter and the 
largest energy consumer in the world, the country's leadership in Beijing found itself increasingly exposed to negative outside opinions, instant judgments, and often harsh criticism. With baubles of blame hung one by one on the giant Christmas tree of China, the country became the common target for international criticism and the censure of analysts (Zhang 2010d).

It remains debatable, of course, whether or not such foreign criticism is well-founded. China's carbon intensity pledge is a case in point. In the run-up to the Copenhagen climate change summit in December 2009, Beijing announced its commitment to cutting carbon intensity by 40 to 45 percent relative to the 2005 level by 2020. This pledge also stressed that renewable and nuclear energy would account for $15 \%$ of the country's primary energy consumption by 2020 , and that China would expand forest cover by 40 million hectares and forest volume by 1.3 billion cubic meters relative to 2005 . These commitments, deemed ambitious by the Chinese government, were quickly dismissed by some Western scholars (e.g. Levi 2009).

To put China's climate pledge into perspective, Zhang (2010f,g) examines whether China's proposed carbon intensity goal for 2020 is as challenging as the energy-saving goals set in the $11^{\text {th }}$ five-year (2006-2010) economic blueprint, to what extent it drives China's emissions below its projected baseline levels, and whether China will fulfill its part in a coordinated global commitment to stabilize the concentration of greenhouse gas emissions in the atmosphere at a desirable level. It is found that the proposed carbon intensity target certainly does not just represent 'business as usual', as some Western scholars have argued. On the other hand, that target may not be quite as ambitious as China argues. Given that China is already the world's largest carbon emitter and its share in the world's total emissions continues to rise, even a few additional percentage reductions in its carbon intensity translate into a significant amount of global emissions reductions. It is hard, but not impossible, for China to increase its own proposed carbon intensity reduction target. Zhang (2010f,g) suggests that China should aim for a 46-50\% cut in its carbon intensity over the period 2006-2020. This 46-50\% carbon intensity reduction will lead to China's emissions reductions of $15-21 \%$ compared with its baseline levels in 2020 (Zhang 2010f,g and 2011). That will put China's absolute emissions reductions very much within the Intergovernmental Panel on Climate Change's recommended level of 15-30\% below their baseline levels by 2020 for developing countries (IPCC 2007).

Despite hard evidence of China's progress in reducing the growth rate of carbon emissions, foreign discourses on China's commitment to energy-saving measures are still characterized by skepticism. Yet the Chinese government has thus far rigorously implemented a wide array of energy-saving and climate mitigation measures, including the closure of inefficient fossil fuelfired power plants, with total combined capacity of over 72 gigawatts (GW) since 2006; the signing of government-industry energy-saving and pollution-cutting agreements known as the "Top 1000 Enterprises Energy Conservation Program"; the improvement of fuel economy standards that are now more stringent than those in Australia, Canada, California and the United States; and the introduction of feed-in tariffs for the increased use of wind energy. ${ }^{5}$ To put scale of China's renewable energy expansion into perspective, China invested $\$ 36.6$ billion in renewable energy in 2009, eclipsing the U.S. investment of $\$ 18.6$ billion in the same year. Also, China continues to upscale its renewable energy target, where it now aims to have an installed capacity of at least $300 \mathrm{GW}$ in hydropower, $180 \mathrm{GW}$ for wind power, and $30 \mathrm{GW}$ for biopower and to produce 10 million tons of ethanol and 2 million tons of biodiesel by 2020 (Zhang 2010b and 2011). Moreover, if China fulfills its pledge, it will do so almost entirely through its own actions;

\footnotetext{
${ }^{5}$ For further discussion on energy-saving and pollution-cutting measures implemented in China, see for instance Zhang (2010b,d and 2011).
} 
unlike many industrial countries, which rely on international off-set markets. However, foreign analysts often highlight anxieties about data accuracy, transparency and monitoring capacity, rather than analyzing with care these various kinds of institutional progress. Realist perspectives define China's motivation for its international climate regime very narrowly: to "protect its sovereignty, acquire foreign aid and technical assistance, and promote its economic development" (Harris 2005, p.24).

While these are certainly important incentives for any developing country to implement a multilateral environmental regime, such a simplistic portrayal of the decisions made by the Beijing leadership overlooks a complex yet steady shift that is taking place within China's foreign policy priorities. There is no doubt that Beijing is now well aware of the risks posed by climate change and other environmental threats that the country may face in the future. At the same time, Beijing sees the practical benefits of its participation in multilateral arrangements, which offer a way to reduce its vulnerability to climate change, improve diplomatic relations and build strategic partnerships for a low-carbon growth path (Hanson 2010).

This ongoing shift reflects at least two of the important trends underlying China's environmental diplomacy. Firstly, China's foreign policy, as recognized by many, is in a transitional phase; the country embraces its "dual identity of Great Power and a developing country" (Shuisheng 2010). Given this dual identity, Beijing increasingly acknowledges its responsibility to meet domestic and regional needs, embracing the notion of "responsible developing country". Through this notion, the Beijing leadership reinforces the country's commitment to peaceful co-existence with the international community. This is not to suggest that China has radically shifted from its traditional claim that developed countries should be held more accountable in areas such as climate change mitigation. ${ }^{6}$ On the contrary, Beijing continues to insist firmly on the principle of common but differentiated responsibilities, as evident in China's strong resistance to the longterm emission caps proposed by developed countries at Copenhagen in December 2009. Rather, China's adjustment to its foreign policy simply implies that it is repositioning itself as a major player, seeking to balance its domestic development needs with those of compliance with the expectations set forth by the international community.

Secondly, China is already moving away from its previous "development first, treat pollution later" economic path (Zhang 2007b). Chinese decision-makers are becoming increasingly proactive, giving greater consideration to environmental concerns. Within these broader changes, issues such as climate change are given priority, as a potential threat to the economy and population is highlighted (Moore 2009; Jacobson 2009). For example, this ascendency of environmental issues, and climate change in particular, is reflected in the official opinions on the 12th five-year plan, delivered at the Chinese Communist Party (CCP) Plenum in October 2010. Considered as one of the most comprehensive and clear statement on CCP's stance regarding

${ }^{6}$ China's insistence on developed country accountability led to strong criticism during the Copenhagen negotiations. French President Nicolas Sarkozy openly criticized China, stating that it had impeded progress in the negotiations (Watts 2009). As discussed further in Zhang (2010a), China could have avoided such an accusation by insisting on the $80 \%$ emission reduction goal for developed countries, and demanding in addition that in 2050 the per capita greenhouse gas emissions for all major countries should be no more than the world's average at that time. In any case, Zhang (2010a) argues that rejecting a longstanding, widely reported proposal without putting forward alternatives cast China in a very bad light. It led to the impression that rich countries should not even announce their unilateral cut - at least, this was the impression reported by the Western media. 
climate change, this option stressed the importance of people-oriented principle and the strengthening of climate change mitigation (Seligsohn 2010). Hence, Beijing recognizes that the country's diplomatic challenges may be intensified by its own demand for resources together with uncertainties arising from transboundary and global environmental issues. As such, the Chinese leadership carefully balances its need for development and self-determination on the one hand, with the need for dialogue and collaboration on the other.

\section{III.2. Environmental Security Concerns and China's Evolving Diplomacy}

Given the interdependence of environmental issues and demand for resources, China will be required to take on greater responsibilities in a regional context. As a natural and inevitable outcome of China's growing economic and environmental footprints, its presence both regionally and on a worldwide basis will also increase. This section reviews some of the major environmental security issues confronting China and its neighbors, and illustrates the role that these non-traditional security risks are likely to play in China's evolving foreign relations.

\section{Northeast Asia: Acid Rain and Yellow Dust}

In Northeast Asia, both acid rain and yellow sand pose environmental and public health threats to China and its neighbors. Acid rain, caused by $\mathrm{SO}_{2}$ and $\mathrm{NOx}$ emissions due to fossil fuel combustion, affects approximately one third of China's landmass, harming the country's vital soil and water resources as well as forest health and China's cultural heritage (Vennemo et al. 2009). In China, acid rain falls mainly in the South, due to naturally existing basic dust components found in the North, which neutralize acid rain. In 2009, acid rain fell on 258 cities and counties of China, many of which were located in the region as far west as the Qinghai-Tibet Plateau to south of the Yangze River, and around Sichuan (Chen 2007).

China has taken rigorous efforts to regulate $\mathrm{SO}_{2}$ emissions, including the phasing-out of small and inefficient coal-fired power plants, and the required installation of flue gas desulferization (FGD) systems for coal-fired plants. The coal-fired units installed with FGD increased to $470 \mathrm{GW}$ in 2009 from $53 \mathrm{GW}$ in 2005. Accordingly, the portion of coal-fired generation capacity with FGD rose to over $80 \%$ in 2010 of the total installed thermal capacity from 13.5\% in 2005 (Zhang 2010b and 2011). However, despite such unprecedented efforts, the areas affected by acid rain are reported to have grown, and an increased acidity has been recorded in some of these areas (Zhao et al. 2009; Jing 2011). This trend is of particular concern since, as Zhao et al. (2009) estimate, the success of rigorous $\mathrm{SO}_{2}$ reduction may be largely offset by an anticipated increase in NOx emissions due to increased power generation and rapid motorization. To combat this increase, the Chinese authorities are currently considering the introduction of a reduction target for NOx, along with additional control measures, in the next five-year plan (Jing 2011). In China, acid rain afflicts the country's already low-quality soil and water, which are threatened at the same time by a number of man-made pressures including deforestation, urbanization, population growth and industrialization.

Due to the apparent time-lag caused by the lengthy soil response to acid deposition, the real impact of acid rain is still unclear, although early signs of soil degradation have also been observed in China, such as the case of red and red-yellow sand in South and Southeast China (Chen 2007). These acid deposits are known to slowly alter soil structure and chemistry, thereby reducing land arability, while also affecting soil biodiversity and carbon content. Of course, such trends may also be exacerbated by other anthropogenic stresses, including the over-application of fertilizer (Guo et al. 2011). These trends are likely to affect long-term land arability and forest growth in China (Chen 2007; Vennemo et al. 2009.) 
Yellow sand, a vital sign of severe soil erosion, also poses considerable health risks to China and its neighbors. Decades of rapid industrialization and land conversion have led to severe deforestation and grassland degradation in much of China's northwest region. These, together with other complex triggers, have caused seasonal dust and sand storms. In the 1950s, the region experienced on average about 5 dust and sand storms annually. This figure steadily increased: it was 14 times higher in the 1970s, and 23 times higher in the 1990s (UNEP 2004). The magnitude of the destruction caused by sandstorms is indeed alarming. For example, in 1993 alone, a dust storm caused 85 deaths, 264 injuries, 373,000 ha of crop damage and additional damage to livestock in Northwestern China, with direct damage totaling US\$ 66 million. In 2006, a severe sand storm caused two deaths along with total economic damage of more than US\$1.25 million (Brettell 2007; UNEP 2004). The leeward countries of Korea and Japan also report frequent damages. In March 2002, for example, a major storm prompted Korea to close 4,949 schools and cancel 40 flights at Gimpo Airport (Yamamoto 2007; UNEP 2004). Japan has also been affected (although to a lesser extent), and the effects on health care in particular have raised public concern.

The fact that these are transboundary issues has been propelling China to join a multilateral collaboration. A gradual shift in Beijing's reactions to regional initiatives reflects China's recognition of the magnitude of these issues, which has led the country to take a more active role in policy dialogue.

Regarding acid rain, the history of collaboration dates back to the mid-1980s, when the scientific community in Korea and Japan began to suspect that the problem was a transboundary one. Since the late 1980s, the results of Japanese studies indicated excessive deposition as compared with national SO2 emissions (Brettell \& Kawashima 1998). Likewise, in 1987, a Korean study conducted on Baekyung Island by the Korean National Institute of Environmental Research (NIER) confirmed that acid deposition in Korea is also affected by air pollution from China (Yoon \& Lee 1998). In response, Japan and Korea both advocated stronger regional collaboration, with Japan's Environmental Agency calling in 1991 for the establishment of an Acid Deposition Monitoring Network in East Asia (EANET), and Korea's NIER demanding in 1999 that a Joint Research Project on Long-Range Air Pollutants (LTP) be implemented by China, Japan and Korea (Nam 2002).

China's initial reaction to these regional initiatives was characterized by ambivalence. Although China had participated in joint research in earlier years, it was not until 1992 that it officially acknowledged its partial responsibility for the acid rain problem (Brettell 2007). Even within the framework of the EANET, Beijing showed an initial reluctance to participate on a formal basis. The Chinese delegate cited domestic demands for the establishment of a State Environmental Protection Agency (SEPA) as a reason to postpone official participation. However, China accepted official member status in December 1998, and subsequently became one of the most enthusiastic members of this acid rain initiative (Takahashi 2002; Nam 2002). ${ }^{7}$

\footnotetext{
${ }^{7}$ Since its official commencement in 2001, membership of the EANET has grown to 14 countries of Northeast and Southeast Asia, with 56 wet deposition and 47 dry deposition monitoring sites as well as 19 ecological monitoring sites operating across the region. These monitoring data are made available online, and the EANET holds periodic policy dialogues, capacity-building and technical training for member countries (EANET website; Zhang 2008). Despite such efforts, however, uncertainty remains as to whether this initiative will become a successful regulatory regime with mandatory reduction targets. Its future success relies on many factors, including a secure financial base, an improved scientific consensus, better coordination and the continued willingness to participate on behalf of China (Takahashi 2002; Brettell 2007).
} 
Governments in the region also began collaborative work to address the issue of yellow sand. The Tripartite Environment Ministers' Meetings (TEMM), held annually with delegates from China, Japan and Korea, provide a common platform for dialogue on this issue. Since 2000, cooperation developed from a joint workshop to afforestation and monitoring projects, and eventually to an initiative to create the Yellow Dust Monitoring Network. The three governments have been working since 2004 with the Asian Development Bank (ADB), the Global Environmental Facility (GEF), and several other UN organizations on a project for regional dust and sandstorm monitoring and early warning (Brettell 2007; Zhang 2008). Of the many initiatives which exist in the region, TEMM is considered one of the most active partnerships, providing an important forum for policy dialogue, including climate change issues. These case studies illustrate not only that the Chinese authorities recognize their regional responsibilities, but also that regional collaboration could bring tangible benefits to China, in the form of improved access to information and monitoring capabilities, and better diplomatic relationships with neighboring countries. While the worsening problems of acid rain and yellow sand pose a great threat to environmental security in the region, the Chinese government is joining the regional dialogue to address these challenges.

\section{Southeast Asia: Hydropolitics of Mekong River Delta}

China's interests are inextricably linked to those of Southeast Asia, and will increasingly be so in years to come. Economically, China is already ASEAN's largest trade partner, and ASEAN is China's third, thanks to the ASEAN-China Free Trade Agreement (FTA), which came into effect on January 1, 2010 (People's Daily 2010; Guo and Cheng 2011). From a security perspective, moreover, Southeast Asia is of critical importance: several of China's major maritime choke points, including the straits of Malacca, Lombok, Makassar and Sunda and the South China Sea, hold strategic significance here (Vaughn and Morrison 2006). Among the region's important nontraditional security agendas is water resource management, which significantly reflects the interplay of these diplomatic considerations.

Beijing had been criticized for many years for its general reluctance to join multilateral engagements relating to the affairs of Southeast Asia. Sino-Southeast Asia relations were long characterized by "suspicion and fear" (Vaughn and Morrison 2006), as exemplified by the controversies over the management of the Mekong River. However, the hostility of regional diplomacy is gradually waning as China shows greater flexibility and readiness to collaborate with its Southeast Asian neighbors.

The Mekong River, with a total length of $4,880 \mathrm{~km}$, runs through China, Myanmar, Laos, Thailand, Cambodia and Vietnam, providing a vital water source for the local population and the environment. Historically, the Mekong River has been of cultural and economic importance to the region's estimated 80 million people, who depend on the river for irrigation water, drinking water, freshwater fishing, and other uses (Osborne 2004; Goh 2009).

These dynamic and rapidly growing riparian states collectively form the vulnerable basin of the Mekong River, where hydropower expansion and deteriorating water quality due to industrial and agricultural uses have caused increased water stress over the years (Osborne 2004: Goh 2009). China, as the upper-stream stakeholder, has principal leverage over the management of the Mekong River. To illustrate, it is commonly estimated that the Chinese basin contributes on average $16 \%$ of run-off to the Mekong River. China's contribution is particularly crucial during 
dry seasons, when as much as $40 \%$ of the river's water is supplied by the Chinese basin (Osborne 2004). Any major developments in navigation and hydropower along this portion of the Mekong River, therefore, could have a damaging effect on downstream ecosystems and livelihoods. It is widely agreed that mega-scale dam construction could damage the fragile river system by altering water flow and silt transportation. Reduced annual silt delivery would not only hamper agricultural productivity downstream, but would also severely impact wild fish catch, which could in turn threaten food security in the region (Osborne 2004; Cronin and Hamlin 2010).

As such, the downstream riparian states have repeatedly requested that China participate in multilateral consultation. In 1995, these states established the Mekong River Commission (MRC) to address regional concerns regarding sustainable river basin management. Since the inception of the MRC, China and Myanmar have refrained from official participation, for which they have been frequently criticized (Morton 2008; Goh 2009). China has thus far constructed three of fifteen planned hydroelectric dams along the Mekong River. When completed, the project's total generation capacity will exceed $25.2 \mathrm{GW}$, with an annual power generation of 120 terawatt-hour (Li 2008), serving as a vital backbone of China's West-to-East power transmission program.

Responding to these rising concerns, the Chinese authorities have repeatedly stressed that dam construction does not harm the environment, and it will also bring a stream of benefits to the region, including improved navigation and flood and drought control. Indeed, the production of hydropower could also help to minimize the use of coal, which in the long run contributes to climate change (Li 2008).

China's general reluctance to participate in multi-lateral engagement stems from at least two response factors. First, water scarcity is a pressing issue for China. Highly uneven water availability, rising demand and declining water quality all pose increasing water stress, particularly in Northern China. China's per capita water availability of $2200 \mathrm{~m}^{3} /$ year is merely a quarter of the world's average (Liu et al. 2007), with Northern China supporting the water demands of as much as $45.2 \%$ of the country's population, despite possessing only $19 . \%$ of China's total water resources (Jiang 2009). Water quality is also declining in many parts of the country. For example, some $60 \%$ of all Chinese rivers are classified as unsuitable for providing drinking water (i.e. Class IV or worse), and half of the country's 27 major lakes also contain water unsuitable for any human uses (Vennemo et al. 2009). As such, the water issue is of increasing importance to China. This fact is also exacerbated by the frequent occurrence of floods, droughts and other hydrological hazards; in the first half of 2010 alone, catastrophic floods in China resulted in 392 deaths and 143 missing people, affecting a further 72.97 million people and damaging 4.63 million hectares of cropland (China Daily 2010b; Lei 2010). Secondly, China's unique geography makes transboundary management of such a scarce resource particularly challenging. Currently, China shares 18 major international river basins with its neighboring countries, including Amur, Ganges-Brahmaputra-Meghna, Har Us Nur, Hsi/Bei Jiang, Indus, Irrawaddy, Mekong, Pu-Lun-To, Red/Song Hong, Salween, Sujfun, Tarim, Tumen and more than 40 tributaries (Wolf et al. 1999; Backer 2007; Yan \& Daming 2009). In many cases, China is the upper-stream riparian state in these international river basins. The Chinese government fears, therefore, and quite reasonably so, that its handing of the Mekong River may expose it to similar demands by other downstream states, complicating already fragile water resource configurations (Backer 2007). As such, Beijing has generally been reluctant to join multilateral discussion on this issue.

Despite such concerns, however, the Chinese government has also shown an increased flexibility and readiness to collaborate with its Southeast Asian neighbors. In many ways, the severe drought in spring 2010 catalyzed such collaboration. In April 2010, the MRC convened its first summit in 
Hua Hin, Thailand, where the member state delegates discussed pressing issues concerning the management of the Mekong River. The Chinese delegation, led by Vice Foreign Minister Song Tao, also participated, reaffirming China's commitment to pursuing enhanced regional partnership in this matter. Making such symbolic gestures as sharing dry season data for the first time, the Chinese representative emphasized that the severe drought was due to the forces of nature, and not China's hydropower developments. Moreover, the Chinese delegation proposed to the MRC six possible avenues for further partnership. These included expanded collaboration through the ASEAN-China FTA on the issues of environmental impact assessment, agricultural trade and development, and transportation and tourism; and joint work on regional natural disaster reduction capacity-building (China Daily 2010c).

Following this meeting, the Chinese authority also invited MRC members to visit the Xiaowan and Jing Hong dams in Yunnan province. The MRC representatives visited the dams for the first time in June 2010, marking an important step in the process of moving dialogue forward. During this visit, the Chinese authorities shared information on hydropower project planning and design, and assured the MRC that China's projects would not have a severe impact on downstream water flow. In addition, the Chinese experts also organized flood and drought management training sessions for the MRC members (MRC 2010). As exemplified in these gestures, the Chinese government is adopting an increasingly open stance towards its Southeast Asian neighbors, as well as identifying strategic channels for further partnerships. ${ }^{8}$

In addition to the Mekong River cooperation, regional forums such as ASEAN Plus Three offer China's Northeast and Southeast Asian neighbors an opportunity to strengthen their partnership with China. Within this framework, the ASEAN members and China, Japan and South Korea have held annual Environment Ministers Meetings since 2002, and have exchanged information regarding environmental cooperation and other issues of strategic importance (ASEAN 2002). Through the establishment of the East Asia Summit (EAS) in 2005, and the endorsement of the Singapore Declaration on Climate Change, Energy and the Environment in 2007 (ASEAN 2007), ${ }^{9}$ these efforts have also been increasingly formalized. Building on these initiatives, China also established the China-ASEAN Environmental Protection Center in March 2010; this center is expected to play an important role in fostering exchange and environmental collaboration (MEP 2010).

${ }^{8}$ In addition to transboundary water management, land use change poses another concern in the region. As the world's largest consumer of many industrial materials, including rubber, the Chinese government has promoted rubber plantation in the region through multilateral and bilateral initiatives. According to a recent study by Ziegler et al. (2009), the extent of land conversion may exceed 50,000 ha in China's uplands and adjacent countries, and demands for land could double or triple by the year 2050. Such an extensive conversion could have a devastating impact on ecosystems and livelihoods, leading to loss of biodiversity, carbon lease and the potential depletion of water resources. The mechanisms of environmental impacts of such conversion are difficult to identify, particularly for the region's hydrology calling for careful assessment and collaborative research work in the region.

${ }^{9}$ Although the Singapore Declaration does not include emissions reduction targets, it recognizes the need for collective action, pledging to "commit to the common goal of stabilizing atmospheric greenhouse gas concentrations in the long run, at a level that would prevent dangerous anthropogenic interference with the climate system". The declaration also includes the "EASwide aspirational goal of increasing cumulative forest cover in the region by at least 15 million hectares of all types of forests by 2020" (ASEAN 2007). 


\section{Greater Himalayan Region : Local and Ecological Vulnerabilities}

Due to its extreme susceptibility to warming, the Qinghai-Tibetan glacial system is regarded by many as the "canary in the coal mine" of climate change (Morton 2008). Indeed, climate change could pose a significant threat to the Qinghai-Tibetan Plateau in the form of melting permafrost, disappearing glaciers, frequent glacial lake outbreak flooding (GLOF), dwindling water resources and alterations to climate-regulating mechanisms. As such, a myriad of environmental security risks are posed to the highly heterogeneous yet vulnerable populations of China and its South Asian neighbors.

With an average altitude of more than 4,000m, the Qinghai-Tibetan Plateau contains 36,800 glaciers, or as many as 46,300 glaciers if its surrounding areas are included (Yao et al. 2007). This Plateau is often termed the world's "third pole", because of its importance as freshwater reservoir outside the polar regions. The Plateau's ecosystem is characterized by its high vulnerability and endemism, with its unique topography extending to the Tibet Autonomous Region (TAR), Qinghai, Gansu, Yunnan, Sichuan and Xinjiang provinces in China, and parts of India, Pakistan Tajikistan, and Nepal (Cui and Graf 2009). The Qinghai-Tibetan region is of particular importance, as its glacial melt feeds Asia's major rivers, including the Yangze, the Yellow, the Amu Darya, the Indus, the Ganges, the Brahmaputra, the Amu Darya, the Irrawaddy, the Salween and the Mekong. It is commonly estimated that the Himalayan ecosystem supports 150 million people directly (Zurick et al. 2005), while the larger river systems, fed by glacial melt, support as many as 1.3 billion in the Asian region as a whole (Xu et al. 2009). Hence, accelerated glacial melting due to climate change could trigger cascading damage to ecosystems and livelihoods, threatening food security and water security, eroding critical habitats and biodiversity, and multiplying hydrological disaster risks to surrounding areas (Xu et al. 2009; Morton 2008).

Glacial dynamics are indeed complex, with mountain glaciers' slow but continuous downward movement resulting in a natural time-lag between climatic change and glacial response. Moreover, because long-term observations in the remote areas of the Himalayas are lacking, a comprehensive assessment of glacial mass is particularly challenging (Malone 2010). While such a lack of knowledge in itself exposes the region to great uncertainty in times of climate change, emerging scientific evidence also points to a possible, very bleak reality for the Himalayan region. Not only has the retreat of the Himalayan glaciers been indicated by measurements of their termini, but losses in glacial mass have also been reported. According to Yao et al. (2007), the proportion of glacial retreat has steadily increased from $53.4 \%$ (of 116 glaciers surveyed) in the 1950 to 1970 period, to $95 \%$ (of 612 glaciers) in the years from 1990 to 2005. Furthermore, the rate of retreat is also accelerating for these glaciers. To illustrate, both Large and Small Dongkemadi of the Tanggula Mountains were still showing evidence of advance in the 1990s; however, this trend has since reversed into retreat, with Large Dongkemadi retreating as fast as $4.6 \mathrm{~m} /$ year (in 2001) and Small Dongkemadi $2.9 \mathrm{~m} / \mathrm{year}$ (in 2002) (Yao et al. 2007). The region's warming is partly accelerated by the release of so-called "black carbon" - soot generated from the combustion of biomass including wood, crop residues and dung. As a result, the region's temperature has risen by as much as $0.3{ }^{\circ} \mathrm{C}$ per decade, or some three times the global average over the past 50 years (Qiu 2008).

The acceleration of glacial melting may have a series of adverse effects on the surrounding ecosystems and people. In the short term, such effects may manifest themselves as localized phenomena within highly vulnerable high-elevation communities, such as GLOFs and the dwindling of water resources (Malone 2010). What makes this particularly alarming is that such burdens may fall disproportionately on the shoulders of the poor and vulnerable; the high-altitude 
nations of Bhutan and Nepal, for instance, rank $132^{\text {nd }}$ and $144^{\text {th }}$ in the Human Development Index (UNDP 2009), and the Tibetan Autonomous Region also ranks among the poorest regions in China. Sustainable livelihood is therefore already a pressing issue for local communities, even in the absence of glacial melt, and this pronounced imbalance between the polluters and the affected inevitably triggers debate about environmental justice and equity. Projected population growth and ethnic tensions in these regions further complicate the matter (Walsh 2009).

In the longer term, these effects may manifest themselves more gradually as wider regional and global concerns. The total contribution of Himalayan glacial melt to surrounding rivers varies considerably, from a relatively low contribution (1.3\% of the Yellow; $6.6 \%$ of the Mekong; $8.8 \%$ of the Salween) to a high one (40.2\% of the Tarim and $44.8 \%$ of the Indus). These figures also vary seasonally, with glacial and snow melt supplying as much as $70 \%$ of flow to the Indus, the Tarim and the Ganges prior to and after summer monsoons. In the Indus River Basin in Pakistan, for example, glacial and snow melt from the western Himalayas, Hindu Kush and Karakoram supplies some $50 \%$ of run-off to the local population's irrigation system; while in Western China, glacial melt provides $12 \%$ of water flow, supporting as much as $25 \%$ of China's population during dry seasons (Xu et al., 2009). As such, significant alteration to river run-offs could severely affect these highly susceptible regions.

To address these critical concerns, a number of local and regional initiatives have been taken both inside and outside China. For example, the International Centre for Integrated Mountain Development (ICIMD), established in 1983, fosters information exchange, policy dialogue and collaborative projects concerning sustainable livelihood and environmental conservation. The ICIMD is a consortium of eight member countries, including Afghanistan, Bangladesh, Bhutan, China, India Myanmar, Nepal and Pakistan, which works toward common challenges of adaptation and development in the region. On a bilateral basis, Indian and Chinese institutions have also begun discussions regarding joint research to monitor the impact of climate change on glaciers in the region, although a tangible partnership is yet to be established (Lamont 2009). On a domestic level, the Chinese government also promotes energy conservation and the shift to renewable energy use. Since 2001, energy-intensive industries including 7 steel plants, 9 cement producers and 4 paper mills have been shut down in Tibet, and the government has put an end to the commercial logging of natural forestation. The current government's plan for ecological protection includes graze-land protection, afforestation, and water and soil loss control, with an allocation of Yuan 15 billion by 2030 (Xinhua 2010).

As this case illustrates, climate change may trigger complex human security concerns with a distinctive combination of international and local aspects. On the one hand, the inherently transboundary nature of climate change means that any national authority must work with its neighbors to foster enhanced communication regarding shared interests. At the same time, efforts to oppose climate change also demand consideration of unique local needs for sustainable development, calling for community-based resilience building beyond mere reliance on technology-based solutions. Therefore, whether or not, and to what extent, the Chinese leadership can address such regional cooperation and local needs will have a decisive impact on the region's environmental security.

\section{Africa: New Development Partnership}

China's engagement in Africa could prove a fundamental means of capturing the region's potential, and shift the locus of world power to developing countries. However, any development path taken must also respect environmental considerations. The Sino-African relationship has expanded in scope and scale from a foreign aid-oriented relationship in the early 1990s to one based on private-sector trade and investment (Wang 2008). According to recent estimates, Sino- 
African trade has increased from US\$ 4 billion in 1995 to US\$ 106.8 billion in 2008, with Africa now supplying about $30 \%$ of China's total crude oil imports (Vines 2007; Peh and Eyal 2010). As China's dependence on Africa's resources increases, its presence and influence in Africa become ever more significant. Such deepening ties have provided a new source of both hope and anxiety for domestic and international observers. Environmental security within the Sino-African relationship, therefore, is becoming subject to closer international scrutiny.

To foster mutual cooperation, the Forum for China Africa Cooperation (FOCAC) was established in 2000. The Beijing Declaration, adopted at the first Ministerial Meeting, stresses the importance of "just and equitable new international political and economic order" and "the effective participation of developing countries in the international process of decision-making" (MOFA 2000). With these common goals, China and Africa have expanded the scope of their collaboration. Since 2007, when the Chinese government established the China-Africa Development Fund, China has provided invaluable support to the region, including infrastructural development and debt relief for the most heavily indebted African states (China Daily 2010d; Zhang 2007a).

Thus far, China's active involvement in Africa has raised a number of diplomatic and human rights concerns. As frequently pointed out (e.g., Lombard (2006), Taylor (2008), and Kaplinsky et al. (2007)), China's pragmatic relationship with the non-democratic states of Africa has helped to undermine Western efforts to promote and protect human rights and good governance. China has demonstrated its capacity and willingness to replace Western investments when these are withdrawn for political reasons. For example, the Chinese state-owned firm China National Petroleum Corporation (CNPC) became the largest share-holder in the Greater Nile Petroleum Operating Company (GNPOC) operating in Sudan, after a Canadian firm withdrew investment due to its concerns about the government's handling of the situation in Darfur. China also extended loans to Angola after non-transparency concerns led to the suspension of the Western donors' conference in 2005 (Kaplinsky et al. 2007). For these reasons, China's growing ties with the African states began to worry Western observers.

While human rights concerns are well-documented, environmental impact per se has received less attention. This is due to the unavailability of detailed information on China's commercial engagement in Africa. This lack of transparency and available information further feeds Western anxieties (Peh and Eyal 2010). Limited studies have merely pointed out a lack of civil society participation in China's project implementations. Coupled with the inadequate undertaking of, or follow-ups to, environmental impact assessments, this may be of increasing concern - as in the cases of the Loango National Park in Gabon and the Merowe Dam in Sudan (Bosshard 2008; Kaplinsky et al. 2007). Certainly, further research will be needed to gauge the environmental impact of China's involvement in Africa.

While concerns remain, it is important to remember that China's engagement also offers considerable assistance to Africa's developmental needs. This is particularly true at the present time, as China continues to support Africa's infrastructural needs after the disengagement of the US and European donors due to economic slowdown (Saches 2010). Under the banner of Southand-South partnerships, China's enhanced involvement could mean a brighter outlook for Africa's economic future. For example, Beijing now promotes the use of Special Economic Zones (SEZ) in Africa - an economic model that has helped to boost China's own economy since the 1980s. Thus far, Chinese firms have taken the initiative to build several such zones in countries such as Algeria, Nigeria, Egypt, Ethiopia, Mauritius, and Zambia (China Economic Review 2010). Regarding China's hunt for oil and natural resources, as long as Chinese state-owned oil majors are trying to acquire sensitive oil assets, political issues will be hard to avoid. To better serve 
China's interests, Chinese majors should team up with Western oil majors in pursuing overseas acquisitions and takeovers. China should be very cautious in pursuing oil diplomacy and business in Africa and other regions, giving proper consideration to the international community's concerns and avoiding coming into direct conflict with Western countries.

While much uncertainty remains as to Africa's future, it is certainly true that China is likely to play a larger role in promoting Africa's human and environmental security; hence, its conduct will receive increased international attention.

\section{III.3. Uncertainty, Risks and other Implications of Climate Change}

Climate change also undermines environmental security in the form of increased uncertainty and risks. It is commonly believed that China will be one of the most affected countries if climate change unfolds as predicted, and among the various consequences anticipated, water security, food security and coastal vulnerability are likely to be of particular concern.

Firstly, climate change will likely affect China's vulnerable hydrology by altering precipitation, evaporation and glacial and snow melt patterns. The recent decades have already shown a worrying sign: the drier North and Northeast China have received less rainfall (a decline of 20 to $40 \mathrm{~mm}$ per decade) since the $1950 \mathrm{~s}$, while the wetter South China has received more precipitation (an increase of 20 to $60 \mathrm{~mm}$ per decade) on average (Wang et al. 2010; Piao et al. 2010). If this trend continues, the already dry Northern China may be subject to an increased risk of drought, while the South may become prone to flooding, adding a significant strain to China's vulnerable hydrology. Perhaps, one of the major risk factors with climate change is that of glacial melting. The common estimates suggest that significant reduction in glacial volume is likely in most cases, with minor glaciers of less than $1 \mathrm{~km}^{2}$ in size being at risk of complete disappearance in the next 50 years. While varied estimates themselves contribute to uncertainty, up to $27 \%$ of glacial area is estimated to vanish by 2050 , and $67 \%$ by 2100 . Such 'tipping point' of glacial melting could pose a formidable challenge to environmental security both inside and outside China (Piao et al. 2010).

Secondly, climate change may threaten China's food security, although the sensitivity of agriculture to changes in climate is difficult to estimate precisely. Depending on various assumptions regarding $\mathrm{CO}_{2}$ fertilization, water availability and the spread of pests and disease, the net impact of climate change on China's agriculture may be positive or negative. In a bleak scenario, China's cereal output could decline by as much as $4-14 \%$ (rice), $2-20 \%$ (wheat) and 0$23 \%$ (maize) by $2050 .{ }^{10}$ With additional environmental degradation such as $\mathrm{O}_{3}$ pollution, grain output could further decline by 7-10\% (rice), 2-7\% (wheat) and 16\% (maize) (Piao et al, 2010). In particular, rain-fed agriculture in North and Northeast China will likely be hit hard, by multiple stresses of precipitation decline, soil moisture shortfall and competing water demands. Currently, these areas account for $38 \%$ of China's total cropland and $24 \%$ of total food output (Tao et al. 2003). Rising temperature and falling rainfall in key pasture regions could also hamper China's livestock production; beef output, for example, is projected to decline by $9.8 \%$ by 2030 (Wang et $a l$. 2010). These trends, coupled with rising demand for food products due to income rise and shifting diet, may drive up food prices worldwide, significantly undermining the food security of vulnerable populations.

Thirdly, sea level rise may have an impact on China major coastal cities. According to China's National Assessment Report on Climate Change, a rise in sea level of $1 \mathrm{~m}$ would inundate as much as $92,000 \mathrm{~km}^{2}$ of the three major industrial areas, including the Gulf of Bohai, the Yangze

\footnotetext{
${ }^{10}$ Without the effect of $\mathrm{CO}_{2}$ fertilization.
} 
River and the Pearl River delta (Zeng et al. 2008). Furthermore, recent evidence suggests that the ice caps may be melting more quickly than anticipated (Rahmstorf, 2007). If melting accelerates further, a $3 \mathrm{~m}$ forecast provides a suitable benchmark, especially when considering increased storm surge risk. Incorporating recent estimates of each country's share of GDP that is exposed with a $3 \mathrm{~m}$ rise in sea levels in coastal zones (Dasgupta et al., 2009), Buys et al. (2009) find that East Asia and the Pacific region is expected to be strongly affected by sea level rise. The effects on Vietnam will be particularly striking, experiencing an exposure of $24.2 \%$ of GDP because of heavy exposure in the Mekong and Red River Deltas. China's exposure is estimated at $5.6 \%$ of GDP. Translated into an absolute value, this exposure will be very large (Buys et al., 2009). Such an impact could indeed jeopardize the region's environmental security, through multiple channels of direct and indirect consequences. Indeed, climate change could place an increased burden on a number of environmental security issues addressed in the previous section.

While enhanced partnerships are certainly needed, one manner in which China chooses to address mitigation strategies could fuel increased anxiety. Heightened tensions are seen not only in areas such as the United States' proposal for border carbon adjustments (Zhang, 2009, 2010c and 2011), but also the future course of international climate change negotiations and peripheral issues such as China's nuclear power development and its handling of the so-called "rare earth metal" trades. What should be stressed here is that these issues will require genuine dialogue and diplomacy if China is to reassure the Western world of its commitment to the path of peaceful development.

Since China's first nuclear power plant was built in Zhejiang in 1983, the Chinese leadership had long remained unsure as to what contribution nuclear power should make to the country's overall energy supply (Zhang, 2010b and 2011). The recent years, however, have seen a marked shift toward expanded nuclear development, due largely to its energy security and the influence of environmental concerns. ${ }^{11}$ In June 2007, the NDRC issued China's medium- and long-term nuclear power development plan, which aimed to add a total installed capacity of $40 \mathrm{GW}$, with another $18 \mathrm{GW}$ under construction by 2020 . This plan was further adjusted in 2009 to reflect an unexpected increase in power demand, coupled with increasing concerns about global climate change and environmental deterioration. The new plan scaled up nuclear power development to the greatest possible extent; accordingly, China's National Energy Administration now aims to have $70 \mathrm{GW}$ or more of nuclear power capacity in operation, with another $30 \mathrm{GW}$ under construction, by 2020 (Zhang 2010b). This will require the construction of 28 additional reactors in the next decade (Wang, 2010).

While China has kept a good safety record, challenges associated with capacity-building and transparency have nevertheless alarmed both domestic and international analysts. To illustrate, China's nuclear industry is estimated to demand an additional 5,000 to 6,000 personnel per year, while domestic institutions can only supply about 2,000 new professional staff annually (Chen

\footnotetext{
${ }^{11}$ A turning point came in early 2004, when China celebrated the $50^{\text {th }}$ anniversary of its nuclear industry establishment. Then, Vice Premier Huang Ju emphasized that special attention should be paid to the future development of nuclear power. This was followed by a media statement by $\mathrm{Xu}$ Kuangdi, the then President of the Chinese Academic of Engineering, which reported that the Chinese government has plans to pursue the active development of nuclear power to replace the existing moderate development. On March 2, 2005, the Premier Wen Jiabao released instructions to adjust China's energy mix and vigorously develop nuclear power. This was widely viewed as a sign that China planned to step up its development of nuclear power (Zhang 2010b).
} 
2010). Such a training gap must be addressed in a collaborative fashion, if the leadership in Beijing is to ease the concerns of its neighbors and China's own population ${ }^{12}$.

Finally, the Beijing leadership may face increased diplomatic tensions in the area of clean energy industry competition. A recent controversy over rare earth elements illustrates this point. These are 17 metallic elements used to produce a number of sophisticated products including hybrid vehicles, wind turbines, energy-efficient light bulbs and military equipment. The world market in these products is currently dominated by China, which supplies some 93 percent of rare earth elements (Bradsher 2009b). In recent years, Beijing introduced a series of production and export quotas to address domestic environmental concerns. Because rare earth metals are used in strategic industries, this greatly alarmed industrial countries, ${ }^{13}$ who speculated as to the real motivation behind Beijing's drastic restriction on rare earth exports (Foster 2010; The Economist 2010). It is unsurprising that such an abrupt decision made without open dialogue would come at a high political cost to China. As the rest of the world diversifies its supply sources, the even worse scenario of supply shock may be averted; however, lack of mutual understanding on this issue could cost China's diplomatic image in the long run.

\section{Concluding Remarks}

Given its population size, geographical scale, economic power and military presence, China is poised to play a larger political role in the twenty-first century, and is thus perceived by the international community to have greater capacities, capabilities and responsibilities. At the same time, environmental stresses caused by China's demands for energy and resources are becoming increasingly evident, urging China to foster delicate diplomatic relations. As has been illustrated, for China to move beyond existing and probable future diplomatic tensions, a greater attention to domestic and regional environmental security will no doubt be necessary. With strong and transparent leadership, China can contribute to environmental security in a number of positive ways.

Firstly, China can further reduce its pollution and demand for natural resources. This reduction may be achieved by the continued promotion of energy efficiency, the widespread use of renewable energy, and strengthened environmental regulations. As China has already committed to quantified energy conservation and clean energy targets, the goals set by the next five-year

${ }^{12}$ No doubt, through more advanced reactor designs and improved operation standards, the likelihood of serious accidents has reduced significantly over the past decades, and should engender less concern today than it did in the 1980s. However, the recent radioactive leak at the Daya Bay plant on May 23, 2010 illustrates that an increased transparency and communication with the public is of paramount importance if Beijing is to ensure safe nuclear power development (Bradsher 2009a). In today's globalized world, if there is a nuclear accident in one country, then it is a nuclear accident for the rest of the world in terms of its chill effect on operations and the development of nuclear power. Thus, it is a matter of self-interest for China and all other countries, regardless of the expansion of their nuclear energy, or the construction of their first nuclear reactor, to adhere to the same high safety standards, particularly given that a renewed interest in nuclear power is apparent in nearly all regions in the world.

${ }^{13}$ As of July 2010, for example, the export quota was reduced to $40 \%$ below the 2009 level. In response, the price of rare earth materials such as cerium oxide and neodymium surged from some US $\$ 8000 / t$ to US $\$ 36,000 / t$, and US $\$ 37,650 / t$ to US $\$ 56,750 / t$ respectively from July 2010 to September 2010 (King 2010). 
economic plan must be as stringent as those of the $11^{\text {th }}$ five-year plan, thereby increasing energy conservation, renewable energy and other low-carbon technologies. Building on China's current plans to decommission thousands of small and inefficient coal-fired power plants with a unit capacity of $50 \mathrm{MW}$ or less, the country could consider doubling or even quadrupling the threshold to $100 \mathrm{MW}$ or $200 \mathrm{MW}$, so that more inefficient plants will be decommissioned. Moreover, China needs to accelerate the restructuring of its industry, remove pervasive subsidies and improve the incentive structure of local governance. Achieving such goals should transform from current reliance on command and control regulations to a policy based on market-oriented instruments. (Zhang 2010b,d). In addition, China can address some of its key hydrological vulnerability by promoting water use efficiency, tacking water pollutions and investing in hydrological disaster risk reductions (DRR).

Secondly, China can foster dialogue, collaboration and information-sharing with its neighbors. As illustrated earlier, a lack of communication and transparency may magnify mutual suspicion and resentment, whereas enhanced dialogue fosters mutual trust among China and its neighbors. Whether via joint research or participation as observers, it is important that all parties involved identify common areas of interest. To foster genuine partnership, the interested parties must design strategic arrangements whereby all countries involved will benefit from active participation. The desired incentives should be such that active participation will yield benefit, rather than penalizing or condemning non-participation. From this standpoint, China's recent gesture to foster dialogue and collaboration within the Mekong River Commission framework is clearly a step in the right direction. An expanding platform for environmental dialogue and cooperation, such as that provided by TEMM and ASEAN Plus Three, also provides further opportunities to address regional environmental security concerns, and the increased involvement of civil society would certainly be desirable.

Finally, China can demonstrate clear political commitment to environmental security. Such a gesture will not only foster collaboration but also avoid unnecessary diplomatic friction. For example, if China well in advance indicates a serious commitment to address climate change in the form of an emissions cap around the year 2030, such a signal will challenge the legitimacy of the U.S. inaction, as well as of proposed carbon tariffs. The positive stance will move climate negotiation forward significantly. For this, it is advisable that China takes absolute emission caps around 2030 with the three transitional periods of increasing climate obligations, namely 1) further credible energy-conservation commitments starting in 2013 ; 2) voluntary "no lose" emission targets starting in 2018; and 3) binding carbon intensity targets staring in 2023, before taking on absolute emissions caps that will lead to the global convergence of per capita emissions by $2050 .{ }^{14}$ However, if China does not present these signals well in advance, that will not help move beyond the existing stalemate of international negotiations, and at the same time the country will continue to face the threat of trade measures (Zhang 2010c). ${ }^{15}$

\footnotetext{
${ }^{14}$ For more discussion please refer to Zhang (2010e and 2011), which lays out a roadmap for China to 2050. Also see Zhang (2000 and 2010c,d,e) for detailed discussion on China's climate strategies regarding the format and timeframe that it would take on climate commitments.

${ }^{15}$ See Zhang (2009, 2010c and 2011) for detailed discussion on the WTO scrutiny of emissions allowance requirements (EAR) under a cap-and-trade regime proposed in the Lieberman-Warner bill in the U.S. Senate and in the Waxman-Markey bill in the U.S. House of Representatives, whether an EAR threat would be effective as an inducement for major emerging economies to take climate actions that they would otherwise not, and methodological challenges in implementing EAR.
} 
Meanwhile, to support China's peaceful development path, the international community must take a practical attitude to the goal of environmental security. As seen in current climate talks, attempting to pressurize China may be counterproductive in achieving the ultimate goal of mitigation. After all, what matters most is the extent to which China cuts its greenhouse gas emissions, and not how it makes its commitments. Continuing to blame China for the inaction of the international community is certainly not a constructive approach. Instead the United States and other developed countries should scale up its technology transfer and deployment, financing and capacity building to enable China to meet the goals. Likewise, in addressing broader concerns about environmental security, the priority should be to reduce the vulnerability of individuals and communities. With these common goals in mind, the international community must demonstrate its own accountability, while China must act as a large and responsible developing country and set a good example for the rest of the world's developing countries.

\section{References}

Allenby, B.R., 2000. Environmental Security: Concept and Implementation. International Political Science Review, 21(1), 5 -21.

Association for Southeast Asian Nations, 2002. The Seventh Informal ASEAN Ministerial Meeting on the Environment and the First ASEAN Plus Three Environment Ministers Meeting. $21 \quad$ November. Available at http://environment.asean.org/index.php?page=media:iamme:7 [Accessed October 19, 2010].

Association for Southeast Asian Nations, 2007. Singapore Declaration on Climate Change, Energy and the Environment. 21 November. Available at http://www.aseansec.org/21116.htm [Accessed October 19, 2010].

Backer, E.B., 2007. The Mekong River Commission: Does It Work, and How Does the Mekong Basin's Geography Influence Its Effectiveness? Journal of Current Southeast Asian Affairs, 26(4), 32-56.

Barnett, J., 2001. The meaning of environmental security: ecological politics and policy in the new security era, Zed Books. London.

Barnett, J., 2003 Security and climate change. Global Environmental Change, 13(1), 7-17.

Barnett, J., \& Adger, W.N., 2007. Climate change, human security and violent conflict. Political Geography, 26(6), 639-655.

Bosshard, P., 2008. China's Environmental Footprint in Africa. Pambazuka News 376: Speaking truth to power: the role of the intellectual. 29 May.

Available at: http://www.pambazuka.org/en/category/comment/48442 [Accessed October $21,2010]$.

Bradsher, K., 2009a. Nuclear Power Expansion in China Stirs Concerns. The New York Times. 16 December. Available at: http://www.nytimes.com/2009

/12/16/business/global/16chinanuke.html?pagewanted=1\&_r=1 [Accessed August 29, 2010].

Bradsher, K., 2009b. China Tightens Grip on Rare Minerals. The New York Times. 1 September. Available at: http://www.nytimes.com/2009/09/01/ business/global/01minerals.html [Accessed August 29, 2010].

Brettell, A., 2007. Security, Energy, and the Environment: The Atmospheric Link. In I.T. Hyun \& M. A. Schreurs (Ed.), The Environmental Dimension of Asian Security. pp. 89-113. United States Institute of Peace

Brettell, A. \& Kawashima, Y., 1998. Sino-Japanese Relations on Acid Rain. In M.A. Schreurs \&D. Pirages (Ed.), Ecological security in northeast Asia. Yonsei University Press. Seoul, pp. 89-113. 
Brown, O., Hammill, A., and McLeman, R., 2007. Climate Change as the 'new' security threat: Implications for Africa. International Affairs, 83(6), 1141-1154.

Buckland, B., 2007. A Climate of War? Stopping the Securitisation of Global Climate Change. Available at: http://www.ipb.org/i/pdf-files/A_Climate_of_War_ Stopping_the_Securitisation_of_Climate_Change.pdf [Accessed February 8, 2011].

Buys, P., Deichmann, U., Meisner, C., Ton That, T. and Wheeler, D., 2009. Country Stakes in Climate Change Negotiations: Two Dimensions of Vulnerability. Climate Policy, 9(3), 288-305.

Callahan, W.A., 2005. How to Understand China: The Dangers and Opportunities of Being a Rising Power. Review of International Studies, 31(04), 701-714.

Chen, A., 2010. China's nuclear sector faces shortage of specialists. Reuters. 20 September. Available at: http://af.reuters.com/article/energyOilNews/ idAFTOE68J04920100920 [Accessed September 29, 2010].

Chen, J., 2007. Rapid Urbanization in China: A Real Challenge to Soil Protection and Food Security. Catena, 69(1), 1-15.

China Daily, 2010a. When Will China Economy Surpass US? 17 August. Available at: http://www.chinadaily.com.cn/opinion/2010-08/17/content_11166379.htm [Accessed October 16, 2010].

China Daily, 2010b. China to boost co-op with downstream Mekong countries. 4 April. Available at:http://www.chinadaily.com.cn/china/2010-04/04/content _9685698.htm [Accessed August 29, 2010].

China Daily, 2010b. Floods kill 392 in China so far this year. 30 June 30. Available at: http://www.chinadaily.com.cn/china/2010-06/30/content_10042379.htm [Accessed September 20, 2010].

China Daily, 2010c. China to boost co-op with downstream Mekong countries. 4 April. Available at:http://www.chinadaily.com.cn/china/2010-04/04/content _9685698.htm [Accessed August 29, 2010].

China Daily, 2010d. China-Africa Forum Benefits Strategic Ties. 12 October. Available at http://www.chinadaily.com.cn/china/2010-10/12/content_11401155.htm [Accessed October 21,2010].

China Economic Review, 2010. Zoning in on Africa. August. Available at: http://www.chinaeconomicreview.com/cer/2010_08/Zoning_in_on_Africa.html [Accessed October 21, 2010].

Cronin, R. \& Hamlin, T. 2010. Mekong Tipping Point: Hydropower Dams, Human Security and Regional Stability. Henry L. Stimson Center. Available at http://www.stimson.org/images/uploads/research-pdfs/Mekong_Tipping_PointComplete.pdf [Accessed February 11, 2011].

Cui, X., \& G. H.F. 2009. Recent Land Cover Changes on the Tibetan Plateau: A Review. Climate Change, 94 (1-2), 47-61.

Dalby, S., 2002. Environmental Security, University of Minnesota Press.

Dasgupta, S., Laplante, B., Meisner, C., Yan, J. and Wheeler, D., 2009. The Impact of Sea Level Rise on Developing Countries: A Comparative Analysis, Climatic Change, 93(3), 379388.

EANET, Acid Deposition Monitoring Network in East Asia. Available at: http://www.eanet.cc/ [Accessed October 5, 2010].

Foster, P., 2010 China Tightens Stranglehold on Rare Earth Minerals. The Telegraph. 02 June. Available at: http://www.telegraph.co.uk/finance/china-business/7797015/China-tightensstranglehold-on-rare-earth-minerals.html [Accessed Aug 27, 2010].

Freeman, D., 2010 The Missing Link: China, Climate Change and National Security. Asia Paper. Brussels Institute for Contemporary China Studies. Available at: 
http://www.vub.ac.be/biccs/site/assets/files/apapers/Asia\%20papers/201012\%20-

$\% 20 \% 20$ Climate\%20Change\%20Security.pdf [Accessed February 8, 2011].

Galtung, J., 1982. Environment, Development and Military Activity: Towards Alternative Security Doctrines. Universitetsforlaget.

Gleditsch, N.P., 2007 Enviromnetal Change, Security and Coflict In C.A. Crocker, F.O.

Hampson, and P. Aall (Ed.) Leashing the Dogs of War: Conflict Management in a Divided World. United States Institute of Peace.

Goh, E., 2009. China in the Mekong River basin: the regional security implications of resource development on the Lancang Jiang. RSIS Working Paper Series 69. Institute of Defense and Strategic Studies Available at: http://www.isn.ethz.ch/isn/DigitalLibrary/Publications/ Detail/?ots591=4888caa0-b3db-1461-98b9e20e7b9c13d4\&lng=en\&id=27145 [Accessed October 18,2010].

Graeger, N., 1996. Environmental Security? Journal of Peace Research, 33(1), 109-116.

Guo,A., \& Cheng G. 2011. China, ASEAN eye stronger ties. China Daily. 26 January. Available at: http://www.chinadaily.com.cn/world/2011-01/26/content_11917354.htm [Accessed February 14. 2011].

Guo, J.H. Liu, X.J., Zhang, Y., Shen, J.L., Han. W.X., Zhang, W.F., Christie, P., Goulding, K.W.T., Vitousek, P.M., Zhang, F.S., 2011. Significant Acidification in Major Chinese Croplands. Science, 327(5968), 1008-1010.

Hagmann, T., 2005 Confronting the Concept of Environmentally Induced Conflict. Peace Conflict and Development 6, 1-22. Available at: http://www.isn.ethz.ch/isn/DigitalLibrary/Publications/Detail/?ots591=0C54E3B3-1E9CBE1E-2C24-A6A8C7060233\&lng=en\&id=15430 [Accessed on February 8, 2011].

Hallding, K., Han, G., and Olsson, M., 2009. China's Climate-and Energy-security Dilemma: Shaping a New Path of Economic Growth. Journal of Current Chinese Affairs, 38(3), 119-134.

Hanson, A.J, 2010. China As An Environmentally Responsible Citizen. China Papers No. 5. Canadian International Council. Available at: http://www.onlinecic.org/ resourcece/archives/chinapapers/chinapapersno5hansonpdf [Accessed February 9, 2011].

Harris, P.G., 2005. Environmental Politics and Foreign Policy in East Asia: A Survey of China and Japan. In P.G. Harris (Ed.), Confronting environmental change in East and Southeast Asia: eco-politics, foreign policy and sustainable development. United Nations University Press, Tokyo.

Homer-Dixon, T.F., 1991. On the Threshold: Environmental Changes as Causes of Acute Conflict. International Security, 16(2), pp.76-116.

Intergovernmental Panel on Climate Change (IPCC), 2007. Climate Change 2007: Mitigation of Climate Change. Working Group III Contribution to the Fourth Assessment Report, Cambridge University Press, Cambridge.

International Energy Agency (IEA), 2010a. China Overtakes the United States to Become World's Largest Energy Consumer. Available at: http://www.iea.org/index_info.asp?id=1479 [Accessed October 16, 2010].

International Energy Agency (IEA), 2007. World Energy Outlook 2007, Paris. International Energy Agency (IEA), 2010b. World Energy Outlook 2010, Paris. Jackobson, L., 2009. China's Changing Climate The World Today, 65(5), 4-7.

Jiang, Y. 2009. China's Water Scarcity. Journal of Environmental Management 90(11), 31853196.

Jing, L., 2011 A Hard Rain Is Falling As Acid Erodes Beauty. China Daily. 12 January. Available at: http://www.chinadaily.com.cn/usa/2011-01/12/content_11833224.htm [Accessed February 9, 2011]. 
Kaplan, R.D., 2010. Geography of Chinese Power: How Far Can Beijing Reach on Land and at Sea, Foreign Affairs, 89, 22.

Kaplinsky, R., McCormick, D., and Morris, M., 2007. The Impact of China on Sub-Saharan Africa Working Paper 291. Institute of Development Studies.

King, A., 2010. Hike in rare earth prices as China quotas bite. Chemistry and Industry, 17. Available at: http://www.soci.org/Chemistry-and-Industry/CnI-Data/2010/17/ArticleListing?at=News [Accessed September 29, 2010].

Lamont J, 2009. New Delhi and Beijing work to save glaciers of Himalayas. The Financial Times. 3 Aug Available at: http://www.ft.com/cms/s/0/55909f74-7fc4-11de-85dc00144feabdc0.html [Accessed September 26, 2010].

Lei, C., 2010. Ji ji ying dui quan qiu qi hou bian hua zhuoli baozhang zhong guo shui anquan. Available at: http://www.gov.cn/gzdt/2010-04/09/content_1576812.htm [Accessed September 20, 2010].

Levi, M.A., 1995. Is the Environment a National Security Issue? International Security. 20(2), $35-62$.

Levi, M.A., 2009. Assessing China's Carbon-Cutting Proposal. Expert Brief. 30 November. Council on Foreign Relations. Available at: http://www.cfr.org/publication/20862/ assessing_chinas_carboncutting_proposal.html [Accessed October 22, 2010].

Li, H., 2008. Lancang Jian-Mekonghe Zhonghuo jinei Zuixia Youdaxing Shuidian Touchan Fadian. The Xinhua 19 June. Available at: http://www.yn.xinhuanet.com/ newscenter/2008-06/19/content_13590359.htm [Accessed September 18, 2010].

Li, X., 2010. Behind the World's Largest Energy Consumer: China Has a Long Way to Address Economic Restructuring and Energy Conservation. Financial News, July 22. Available at: http://www.financialnews.com.cn/zhjj/txt/2010-07/22/content_300021.htm [Accessed February 15, 2011].

Liu, J., Zehnder, A.J.B., \& Yang H. 2007 Historical Trends in China's Virtual Water Trade. Water International, 32(1), 78-90.

Liu, J., Wang, S., Yu, S., Yang, D., \& Zhang, L. 2009. Climate Warming and Growth of HighElevation Inland Lakes on Tibetan Plateau Global and Planetary Change. 67(3-4), 209217.

Lombard, L., 2006 Africa's China Card. Foreign Policy 11 April. Available at: http://www.foreignpolicy.com/articles/2006/04/10/africas_china_card [Accessed October 19, 2010].

Malone, E. 2010. Changing Glaciers and Hydrology in Asia: Addressing Vulnerabilities to Glacier Melt Impacts. USAID. Available at: http://www.usaid.gov/ locations/asia/documents/Asia_Glacier_Melt_Vulnerability_Nov-2010.pdf [Accessed February 11, 2011].

Mathews, J.T., 1989. Redefining Security. Foreign Affairs, 68(2), 162-177.

Mekong River Commission, 2010. MRC Countries Discuss Increased Cooperation With China/Myanmar In Managing the Mekong. 10 Aug 10. Available at: http://www.mrcmekong.org/MRC_news/press 10/MRC-countries-discuss-27-Aug-10.htm [Accessed September 18, 2010].

Ministry of Environmental Protection, 2010. China-ASEAN Environmental Protection

Center $\backslash$ Established and Li Ganjie Attends the Meeting for Appointment of Its

Leadership. 20 March. Available at http://english.mep.gov.cn/Ministers

/Activities/201006/t20100608_190653.htm [Accessed October 19, 2010].

Ministry of Foreign Affairs, 2000. Beijing Declaration of the Forum on China-Africa Cooperation. $17 \quad$ November. Available at: http://www.fmprc.gov.cn/eng/wjdt/2649/t15775.htm [Accessed October 22, 2010].

Mische, P., 1993. Ecological Security in An Interdependent World. Update on LawRelated Education, 17(3), 52-60. 
Moore, S. 2009. Climate Change, Water and China's National Interest. China Security, 5(3), 25-39 Available at: http://www.chinasecurity.us/pdfs/ScottMoore.pdf [Accessed February 8, 2011].

Morton, K., 2008. China and Environmental Security in the Age of Consequences. Asia-Pacific Review, 15(2), 52-67.

Nam, S., 2002. Ecological Interdependence and Environmental Governance in Northeast Asia: Politics vs. Cooperation. In P.G. Harris (Ed.), International Environmental Cooperation : Politics and Diplomacy in Pacific. The University Press of Colorado, pp. 167-202.

Osborne, M., 2004. River at Risk: The Mekong and Water Politics of China and Southeast Asia. Lowy Institute for International Policy.

Peh, K.S.H. \& Eyal, J., 2010. Unveiling China's impact on African environment. Energy Policy 38(8), 4729-4730.

People's Daily. 2010. ASEAN surpasses Japan as China's r3d largest trade partner. 18 June. Available at: http://english.peopledaily.com.cn/90001/90778/90861/ 7030353.html [Accessed February 14, 2011].

Piao, S., Ciais, P., Huang, Y., Shan, Z., Peng, S., Li, J., Zhou, L., Liu, H., Ma, Y., Ding, Y., Friedlingstein, P., Liu, C., Tan, K., Yu, Y., Zhang,T., \& Fang, J. 2010. The impacts of climate change on water resources and agriculture In China. Nature 467, 43-51.

Qiu, J., 2008. China: the Third Pole. Nature 454, 393-396.

Rahmstorf, S., 2007. A Semi-empirical Approach to Projecting Future Sea-level Rise, Science, $315,812-813$.

Raleigh, C., \& Urdal, H. 2007. Climate change, environmental degradation and armed conflict. Political Geography, 26 (6), 674-694.

Ronnfeldt, C. 1997. Three Generations of Environmental and Security Research. Journal of Peace Research, 34(4), 473-482.

Sachs, J., 2010 China has left the west on the sidelines in Africa. The Financial Times Online, Beyondbricks 22 September. Available at: http://blogs.ft.com/beyond-brics/2010/09/22/ jeffrey-sachs-china-has-left-the-west-on-the-sidelines-in-africa/ [Accessed October $21,2010]$.

Schreurs, M.A., 2009. Environmental Security in Northeast Asia. Facing Global Environmental Change, 829-841.

Seligsohn, D., 2010. China's Party Plenum Recommends Climate Actions in the 12th Five Year Plan. China FAQs: The Network for Climate and Energy Information. The World Resources Institute. Available at: http://www.chinafaqs.org/blog-posts/chinasparty-plenum-recommends-climate-actions-12th-five-year-plan [Accessed February 14, 2011].

Shouqiu, C. \& Voigts, M., 1993. The Development of China's Environmental Diplomacy. Pacific Rim Law and Policy Journal, 3, 17-42

Suisheng, Z., 2010 Chinese Foreign Policy under Hu Jintao: The Struggle Between Low-Profile Policy and Diplomatic Activism. The Hague Journal of Diplomacy, 5(4), 357-378.

Sun, G., 2010 Coal in China: Resources, Uses and Advanced Coal Technologies. Coal Initiative Series White Paper. Pew Center for Global Climate Change Available at: http://www.pewclimate.org/publications/whitepaper/coal-initiative -series/coal-china-resources-uses-and-advanced-coal-technology [Accessed February 8, 2011].

Takahashi, W., 2002. Problems of Environmental Cooperation in Northeast Asia: The Case of Acid Rain. In P.G. Harris (Ed.), International Environmental Cooperation: Politics and Diplomacy in Pacific. University Press of Colorado, pp. 221-247.

Tao, F., Yokozawa, M., Hayashi, Y., \& Lin, E. 2003. Future Climate Change, the Agricultural Water Cycle, and Agricultural Production in China. Agriculture, Ecosystems and Environment, 95 (1), 203-215. 
Taylor, I., 2008. Sino-African Relations and the Problem of Human Rights. African Affairs, 107 (426), 63-87.

The Economist, 2010. Rare Earth: Digging. 4-10 September Available at: http://www.economist.com/node/16944034 [Accessed October 17, 2010].

Tseng, N., 2010. Will China top the US's economy in 2030? The CNN Money. 17 August, Available at: http://money.cnn.com/2010/08/17/news/ international/china_economy.fortune/index.htm [Accessed October 16, 2010].

Ullman, R.H. 1983 Redefining Security. International Security, 8(1), 129-153.

United Nations Development Programme, 1994. Human Development Report. Available at: http://hdr.undp.org/en/media/hdr_1994_en_contents.pdf [Accessed February 8, 2011].

United Nations Economic and Social Commission for Asia and the Pacific, 2004. Multistakholder Partnerships in Promoting Sustainable Development in Asia and the Pacific: Prevention and Control of Dust and Standstorms. Available at: http://www.unescap.org/esd/subcommittee/english/SESD_4E.pdf. [Accessed October 18, 2010].

United Nations Framework Convention on Climate Change , 2009. Report of the Conference of the Parties on its fifteenth session, held in Copenhagen from 7 to 19 December 2009. Available at: http://unfecc.int/ resource/docs/2009/cop15/eng/11a01.pdf. [Accessed February 8, 2011].

United Nations General Assembly, 2009. 63/281. Climate change and its possible security implications. Available at: http://daccess-dds-ny.un.org/doc/UNDOC/

GEN/N08/487/65/PDF/N0848765.pdf?OpenElement. [Accessed October 18, 2010].

Vaughn, B. \& Morrison, W.M., 2006. China-Southeast Asia Relations: Trends, Issues, and Implications for United States. CRS Report for Congress. Available at: http://www.fas.org/sgp/crs/row/RL32688.pdf [Accessed February 11, 2011].

Vennemo, H., Aunan, K., Lindhjem, H. \& Seip, H.M. 2009. Environmental Pollution in China: Status and Trends. Review of Environmental Economics and Policy, 3(2), 209230.

Vines, A., 2007. China in Africa: A Mixed Blessing? Current History, 106(700), 213-219.

Walsh, B., 2009. Climate Change: The Tragedy of the Himalayas - COP15: Climate-Change Conference. Time Magazine. Available at: http://www.time.com/time/specials/ packages/article/0,28804,1929071_1929070_1945667-1,00.html [Accessed September 24, 2010].

Wang, J.Y., 2008 Africa's Burgeoning Ties with China. Finance and Development, 45(1):44-47. Available at: http://www.imf.org/external/pubs/ft/fandd/2008/03/pdf/wang.pdf [Accessed October 17, 2010].

Wang, J., Huang, J. \& Rozelle, S. 2010. Climate Change and China's Agricultural Sector: An Overview of Impacts, Adaptation and Mitigation. Issue Brief No. 5 International Centre for Trade and Sustainable Development. Available at: http://www.agritrade.org/events/documents/ClimateChangeChina_final_web.pdf [Accessed February 11, 2011].

Wang, Y., 2010. China to Build 28 More Nuclear Power Reactors by 2020 (Update2) Business Week 23 March. Available at: http://www.businessweek.com/news/2010-03-23/china-tobuild-28-more-nuclear-power-reactors-by-2020-update1-.html [Accessed September 28, 2010.]

Watts, J., 2009. China 'Will Honour Commitments' Regardless of Copenhagen Outcome. The Guardian, 18 December. Available at: http://www.guardian.co.uk/environment/ 2009/dec/18/china-wen-jiabao-copenhagen [Accessed September 24, 2010].

Wolf, A.T., Natharius, J.A., Danielson, J.F., Ward, B.S., \& Pender, J.K., 1999. 
International River Basins of the World. International Journal of Water Resources Development, 15(4), 387-427.

Xinhua, 2010. Climate Change Hurting Tibet. 5 March. Available at: http://news. xinhuanet.com/english/2010-03/05/content_13100235_1.htm [Accessed September 22, 2010].

Xu, J., Grumbine, R.E., Shrestha, A., Eriksson, M., Yang, X., Wang, Y., \& Wilkes, A., 2009. The Melting Himalayas: Cascading Effects of Climate Change on Water, Biodiversity, and Livelihoods. Conservation Biology, 23(3), 520-530.

Yamamoto,Y., 2007 Recent Moves to Address the Kosa (Yellow Sand) Phenomenon-Towards Solutions for a Problem that is an age-old Natural Phenomenon and has concurrently been Influenced by Anthropogenic- Quarterly Review, 22, 45-61. Available at: http://www.nistep.go.jp/achiev/ftx/eng/stfc/stt022e/qr22pdf/

STTqr2203.pdf [Accessed October 17, 2010].

Yan, F. \& Daming, H. 2009. Transboundary Water Vulnerability and its Drivers in China. Journal of Geographical Sciences, 19(2), 189-199.

Yao, T., Pu, J., Wang, Y., \&Yu, W., 2007. Recent Glacial Retreat and Its Impact on Hydrological Processes on the Tibetan Plateau, China and Surrounding Regions. Arctic, Antarctic and Alpine Research, 39(4), 642-650.

Yoon, E. \& Lee, H.P., 1998. Environmental Cooperation in Northeast Asia: Issues and Prospects. In MA. Schreurs \& D. Pirages (Eds.), Ecological security in northeast Asia. Yonsei University Press. Seoul.

Zeng, N., Ding, Y., Pan, J., Wang, H., \& Gregg, J. , 2008. Climate change- the Chinese challenge. Science, 319(5864), 730-731.

Zhang, Z.X., 2000. Can China Afford to Commit itself an Emissions Cap? An Economic and Political Analysis. Energy Economics, 22(6), 587-614.

Zhang, Z.X., 2007a. China's hunt for oil in Africa in perspective. Energy \& Environment, 18(1), $87-92$.

Zhang, Z.X., 2007b. China is moving away the pattern of "develop first and then treat the pollution". Energy Policy, 35(7), 3547-3549.

Zhang, Z.X., 2008. Asian energy and environmental policy: Promoting growth while preserving the environment. Energy Policy, 36(10), 3905-3924.

Zhang, Z.X., 2009. Multilateral Trade Measures in a Post-2012 Climate Change Regime?: What Can Be Taken from the Montreal Protocol and the WTO?. Energy Policy, 37, 5105-5112.

Zhang, Z.X., 2010a. Copenhagen and Beyond: Reflections on China's Stances and Responses. In E. Cerdá \& Xavier Labandeira (Eds.), Climate Change Policies: Global Challenges and Future Prospects, Edward Elgar, pp. 239-253. Available at: http://www.feem.it/userfiles/ attach/2010712939214NDL2010-091.pdf [Accessed October 18, 2010].

Zhang, Z.X., 2010b. China in the transition to a low-carbon economy. Energy Policy, 38, 66386653.

Zhang, Z.X., 2010c. The U.S. Proposed Carbon Tariffs, WTO Scrutiny and China's Responses, International Economics and Economic Policy, 7(2-3), 203-225.

Zhang, Z.X, 2010d. Is it fair to treat China as a Christmas tree to hang everybody's complaints? Putting its own energy saving into perspective. Energy Economics, 32 (Suppl. 1), S47S56.

Zhang, Z.X., 2010e. In what format and under what timeframe would China take on climate commitments? a roadmap to 2050. International Environmental Agreements: Politics, Law and Economics, forthcoming. Available at: http://www.feem.it/userfiles/attach/20109201035374NDL2010-112.pdf.

Zhang, Z.X., 2010f. Assessing China's Energy Conservation and Carbon Intensity: How Will the Future Differ from the Past?. In: Ross Garnaut, Jane Golley and Ligang Song (Eds), 
China:The Next Twenty Years of Reform and Development, Australian National University E-Press, Brookings Institution Press and China Social Sciences Academic Press, pp. 99-125.

Zhang, Z.X., 2010g. Assessing China's Carbon Intensity Pledge for 2020: Stringency and Credibility Issues and their Implications. Environmental Economics and Policy Studies, doi:10.1007/s10018-011-0012-4.

Zhang, Z.X., 2011. Energy and Environmental Policy in China: Towards a Low-carbon Economy. New Horizons in Environmental Economics Series, Edward Elgar, Cheltenham, UK and Northampton, USA.

Zhao, J., \& Ortolano, L., 2003. The Chinese Government's Role in Implementing Multilateral Environmental Agreements: The Case of the Montreal Protocol. The China Quarterly, $175,708-725$.

Zhao, Y., Duan. L., Xing, J., Larssen, T., Nielsen, C.P., \& Hao, J. 2009. Soil Acidification in China. Is Controlling SO2 Emissions Enough? Environmental Science and Technology, 43(21), 8021-8026.

Ziegler, A.D., Fox, J.M. \& Xu, J., 2009. The rubber juggernaut. Science, 324(5930), 1024.

Zurick, D., Pacheco, J., Shrestha, B., \& Bajracharya, B., 2005. Atlas of the Himalaya. International Centre for Integrated Mountain Development. Available at: http://books.icimod.org/index.php/search/publication/146 [Accessed February 11, 2011]. 